Volume 5, Issue 2 (Summer 2013)

\title{
Incapable of That Sort of Thing: Millet's Dutch Sources
}

Johanna Ruth Epstein

Recommended Citation:

Johanna Ruth Epstein, “Incapable of That Sort of Thing: Millet's Dutch Sources," JHNA 5:2 (Summer 2013), DOI:10.5092/jhna.2013.5.2.17

Available at https://jhna.org/articles/incapable-of-that-sort-of-thing-millets-dutch-sources/

Published by Historians of Netherlandish Art: https://hnanews.org/

Republication Guidelines: https://jhna.org/republication-guidelines/

Notes: This PDF is provided for reference purposes only and may not contain all the functionality or features of the original, online publication. This is a revised PDF that may contain different page numbers from the previous version. Use electronic searching to locate passages. This PDF provides paragraph numbers as well as page numbers for citation purposes.

ISSN: 1949-9833 


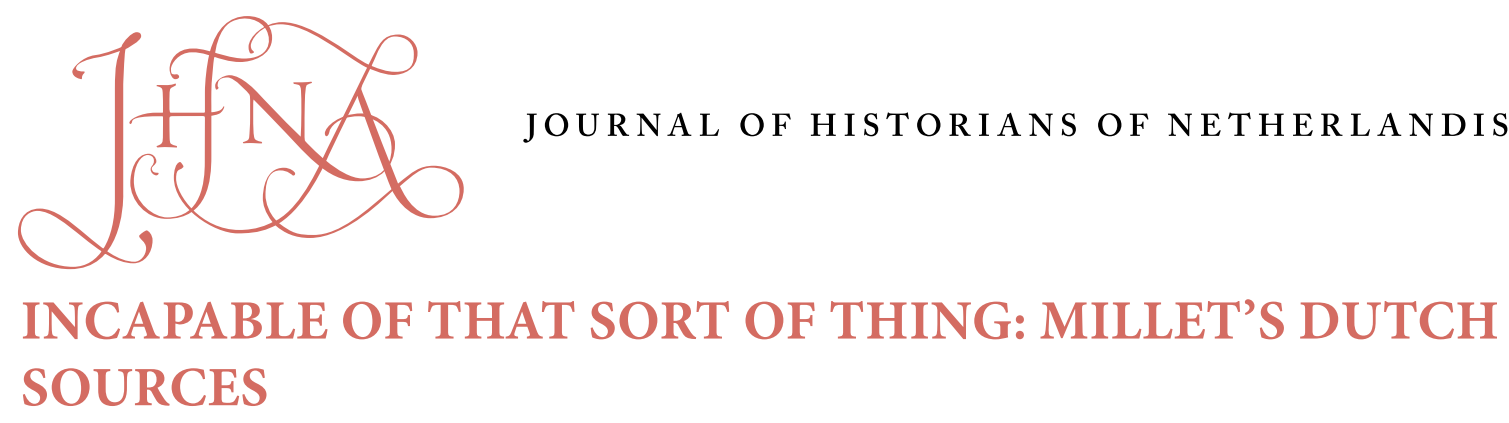

\section{Johanna Ruth Epstein}

In Jean-François Millet's work, what passed for direct observation was often borrowed from Dutch art. This essay reveals a previously unrecognized Dutch source, Jan Luyken, whose popular manual for housewives and book of trades were a treasure trove of source material for Millet's depictions of traditional peasant labor. While Millet's audience assumed his subjects were scenes observed from his everyday life, Luyken and other Dutch sources allowed Millet to cultivate an aesthetic that turned back the clock on industrialism and urbanization, perpetuating the myth that the agrarian lifestyle was resistant to time and change.ue. This contextualization reconciles the painting's identification as allegory, history and portrait historié, and illuminates Lievens's visual sources. 10.5092/jhna.2013.5.2.17 $\mathrm{f}$ one asks to see the visitors' registry in the print room at the Bibliothèque Nationale, the unmistakable signature of Jean-François Millet (1814-1875) appears there in July 1837. It was Millet's first year as a student in Paris. A pupil of Paul Delaroche (1797-1856), he was free to come and go at the library's print room, which gave him access to innumerable treasures.

The Bibliothèque Nationale housed one of the world's premier collections of Dutch prints, over a thousand by Rembrandt alone. In 1837, a special exhibition of highlights from the library's holdings, including eighteen Rembrandt etchings, was on display. ${ }^{1}$ Millet's familiarity with these prints is evident in a drawing of a crouching man hovering over a supine woman (fig. 1), which is clearly based on Rembrandt's Jupiter and Antiope (fig. 2). ${ }^{2}$

3 Through a series of subsequent drawings based on this sketch, Millet transformed Jupiter and Antiope into rural laborers, taming the eroticism of the original version, adding a haystack in the background (fig. 3), reversing the poses, divesting Rembrandt's figures of mythic significance, and finally rendering them as anonymous peasants in the French countryside (fig. 4). These Dutch-inspired figures are the first manifestation of a leitmotif in Millet's later work: the peasant at rest. ${ }^{3}$

The metamorphosis of Rembrandt's mythological figures into modern field laborers (a process realized over several decades) is a microcosm of Millet's lifelong strategy of appropriation from Dutch art: slow, incremental modifications of form and subject, until the result is no longer identifiable with an antecedent, yet is still playing on subtle substrata of meaning. 


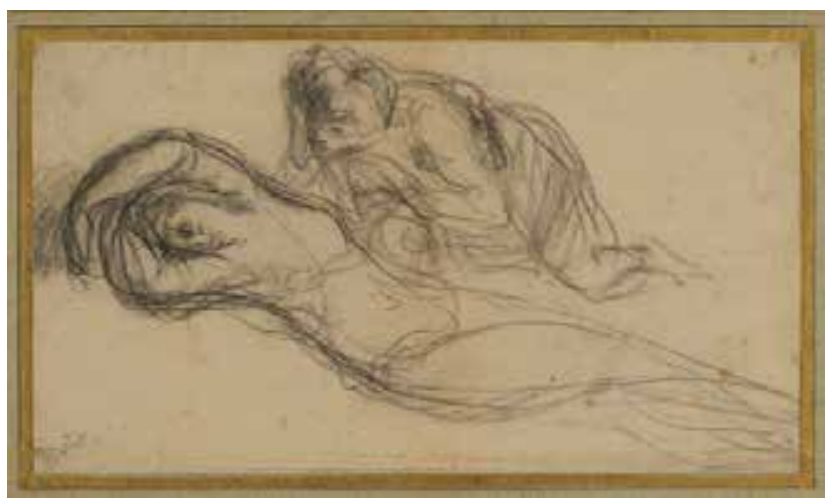

Fig. 1 Jean-François Millet, Daphnis and Chloé, ca. 1848-50, black chalk on paper, $11.4 \times 20.2 \mathrm{~cm}$. National Gallery of Canada, Ottawa, inv. no. 338 (artwork in the public domain)

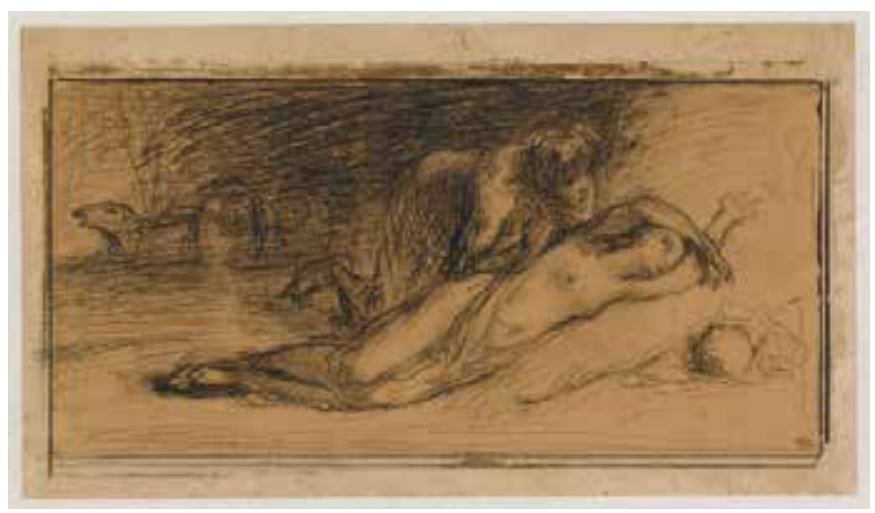

Fig. 3 Jean-François Millet, Femme à moitié nue, étendue au pied d'une meule (Half-naked woman, lying at the base of a haystack), ca. 1846, black chalk on paper, $18.2 \mathrm{~cm} \times 32.2 \mathrm{~cm}$. Musée du Louvre, Département des arts graphiques, Paris, inv. no. RF 5226, recto (artwork in the public domain) Photo: @ Musée du Louvre

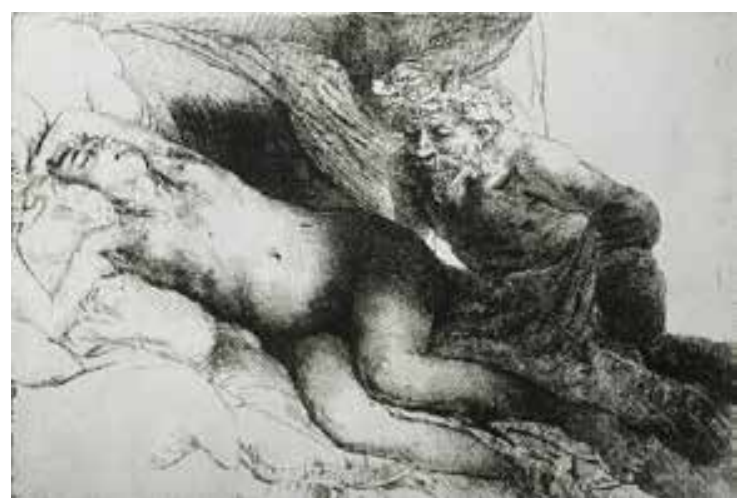

Fig. 2 Rembrandt, Jupiter and Antiope: The Larger Plate, 1659, etching, engraving, and drypoint, first state, $13.8 \times 20.4 \mathrm{~cm}$. Pierpont Morgan Library, New York, inv. no. RvR 289 (artwork in the public domain)

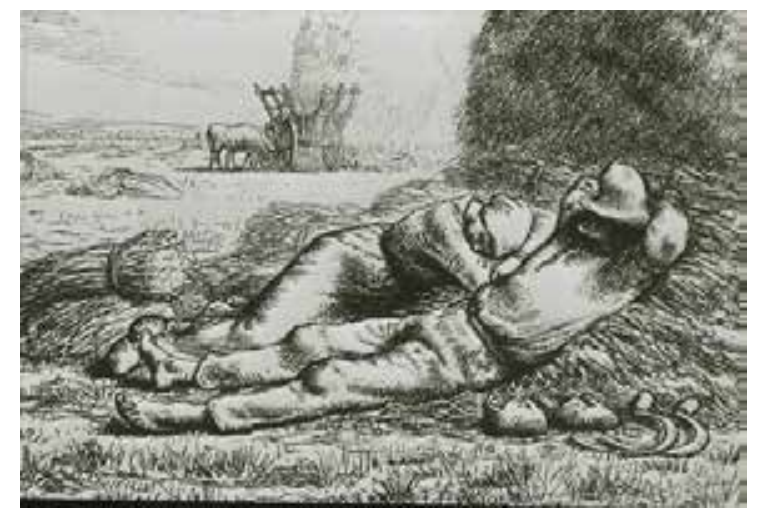

Fig. 4 Jacques Adrien Lavieille (1818-1862) after Jean-François Millet, printed by Jules Claye, Noon, 1860, wood engraving on paper, $14.8 \times 22 \mathrm{~cm}$. The Art Institute of Chicago, inv. no. 1944.75 (artwork in the public domain)

Millet claimed he was "too wise to attempt a copy, even of something of my own; I am incapable of that sort of thing."4 This glaring falsehood is a prime example of the artist's feigned naïveté. In contradiction of his alleged hard line position on copying ("even of something of my own"), he was more than happy to reproduce several of his own compositions for collectors upon request. ${ }^{5}$ Numerous copies survive from his student years, and it was most likely under his first teacher, Bon Dumouchel (1807-1846), who was obsessed with the art of the Low Countries, that Millet began to borrow from Dutch prints. ${ }^{6}$

6 Nearly every major study of Millet acknowledges the presence of a Dutch aesthetic in his work. In 1970, Robert Herbert even referred to the 1850s as the artist's "Dutch period." The scope of the artist's involvement with Dutch art, however, remains undefined. The most comprehensive discussion of the subject appears in Petra ten-Doesschate Chu's French Realism and the Dutch Masters (1974) and is limited to five of Millet's genre paintings from the 1850s. ${ }^{8}$ My own investigation reveals a new Dutch source for Millet's compositions and a dependence on Dutch art far greater than previously assumed. 
Among the challenges to understanding Millet's relationship to Dutch art is that the artist himself had so little to say on the matter. Tight-lipped on sources in general, Millet allowed critics, dealers and other artists to intercede on his behalf. Foremost among these was Alfred Sensier, the Paris bureaucrat who later became his biographer, who cultivated Millet's image as "a man of the soil... unconcerned with the niceties of civilizations lost in their refinements."'

Recent Millet studies have uncovered a more nuanced individual than the untutored peasant projected by earlier literature on the artist. The son of a prosperous farmer, Millet left home with money in his pocket, never to work on the farm or experience the poverty so often depicted in his mature paintings. As Bruce Laughton has observed, prints, photographs, and drawings were the foundation upon which Millet built his signature aesthetic: "The woodcutters, the harvesters, the sheep-shearers, the shepherdesses, the water carriers, the winnowers and butter churners were first drawn in Paris." 10

9 In the capital's museums, libraries, and print rooms, Millet assembled a visual repertoire that he would continue to develop throughout his life. A thorough knowledge of Dutch prints guided even some of the most informal of his rough sketches from the 1850s. Clearly dependent upon a specific Dutch source is Millet's light pencil sketch Christ among the Doctors (fig. 5), adapted from Rembrandt's etching of the same subject (fig. 6), which he would have seen at the Bibliothèque Nationale.

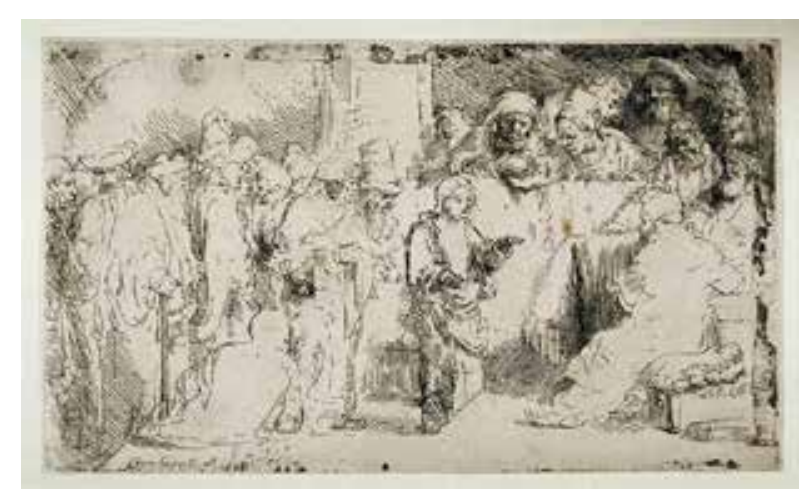

Fig. 5 Jean-François Millet, Christ among the Doctors, mid-1840s, graphite on paper, $19.2 \times 30.1 \mathrm{~cm}$. Musée du Louvre, département des Arts graphiques, Paris, inv. no. RF 5883, recto (artwork in the public domain) Photo: (C) Musée du Louvre

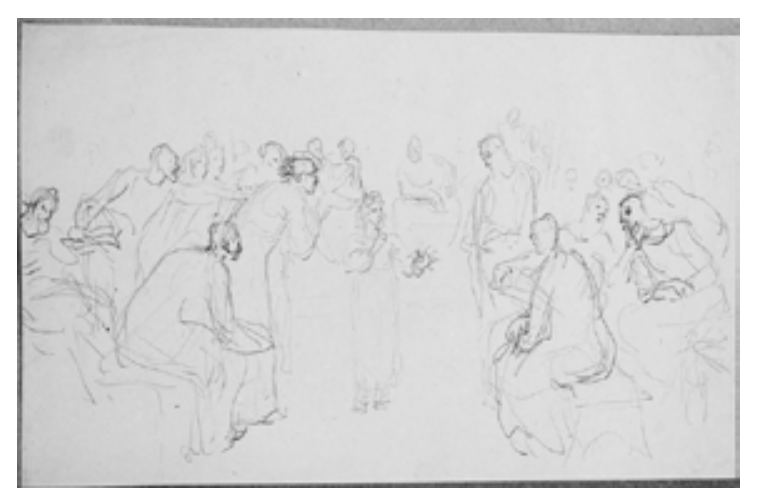

Fig. 6 Rembrandt, Christ among the Doctors, 1652, etching and drypoint, $12.6 \times 21.4 \mathrm{~cm}$. Fine Arts Museums of San Francisco, inv. no. FASF.1821 (artwork in the public domain)

10 Millet not only studied Dutch prints, he also collected them. He was in the habit of asking friends traveling abroad to bring back prints and photographs with rural motifs. Prior to Félix-Bienaimé Feuardent's departure for Italy in 1865, for example, he wrote:

If you find photographs, either from the antique, especially those less known here ... buy them ... Do not take anything out of Raphael; he is to be found in Paris . . bring whatever you find, figures and animals. Diaz's son ... brought some very good ones, sheep among other things. Of figures, take of course those that smack least of the Academy and the model,--in fact, all that is good, ancient or modern, licit or illicit. ${ }^{11}$ 
11 An inventory of items found in the artist's home after the death of his widow lists forty-five engravings by Dutch artists, of whom only three (Rembrandt, Adriaen van Ostade [1610-1685], and Jan Luyken [1649-1712]) are mentioned. ${ }^{12}$ One wishes the notary had listed them all individually, but the simple fact that Millet owned these engravings is of great significance. Luyken, the prolific late-seventeenth century Dutch illustrator, was relatively obscure in France when Millet acquired his etchings. Luyken's two most widely circulated print series were an illustrated manual of mostly male trades, entitled Het Menselyk Bedryf (The Book of Trades), and a practical household manual for wives, Het Leerzaam Huisraad (The Tutelary Household). ${ }^{13}$ To each illustration, Luyken appended a moralistic verse.

12 By the late 1840s, the visual evidence that Millet had acquired these prints is abundant. Consider The Cooper (fig. 7), which marks a decisive shift toward the powerful single-figure studies typical of Realism in the late 1840s, and the strikingly close prototype (fig. 8) in Luyken's Book of Trades, a figure caught in mid-swing, bracing the barrel with his left foot and preparing to strike the chisel above the top hoop. ${ }^{14}$ Even the drape of his apron corresponds with that of Millet's cooper. Young Mother Preparing the Evening Meal (fig. 9), a spare composition from the same period, achieves similar monumentality. Millet's specific source was Luyken's De Pan (The Pan) (fig. 10).

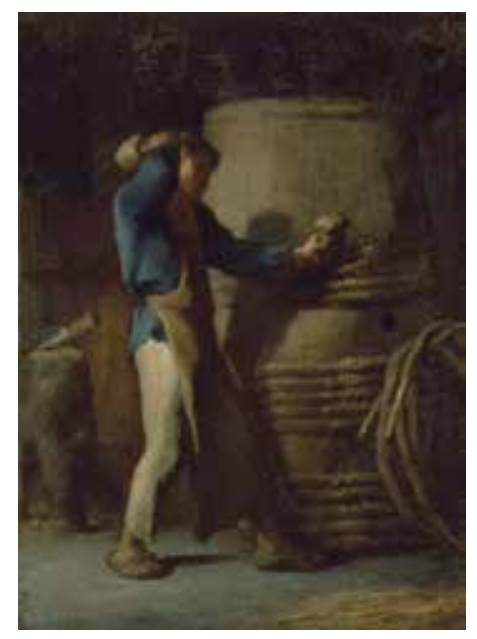

Fig. 7 Jean-François Millet, The Cooper, ca. 1848-50, oil on canvas, $45.1 \times 33.0 \mathrm{~cm}$. Museum of Fine Arts Boston, inv. no. 17.1500 (artwork in the public domain) Photo: ( MFA Boston

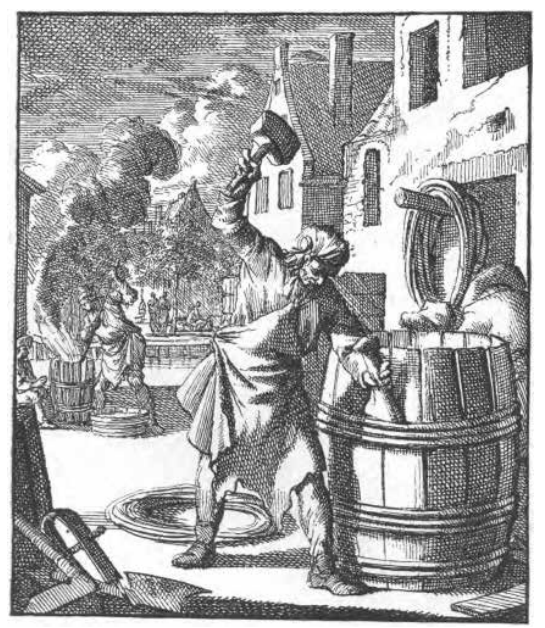

Fig. 8 Jan Luyken, Kuiper (Cooper) from Het Leerzam Huisraad, 1711.

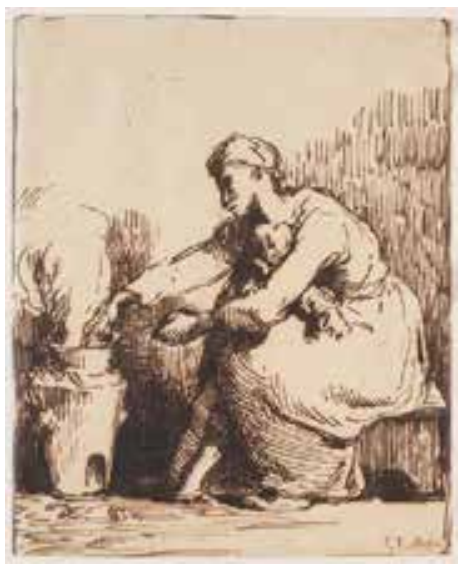

Fig. 9 Jean-François Millet, Young Mother Preparing the Evening Meal, 1848-50, pen and brown ink on paper,20.8 $x 16.8 \mathrm{~cm}$. National Gallery of Canada, Ottawa, inv. no. 339 (artwork in the public domain)

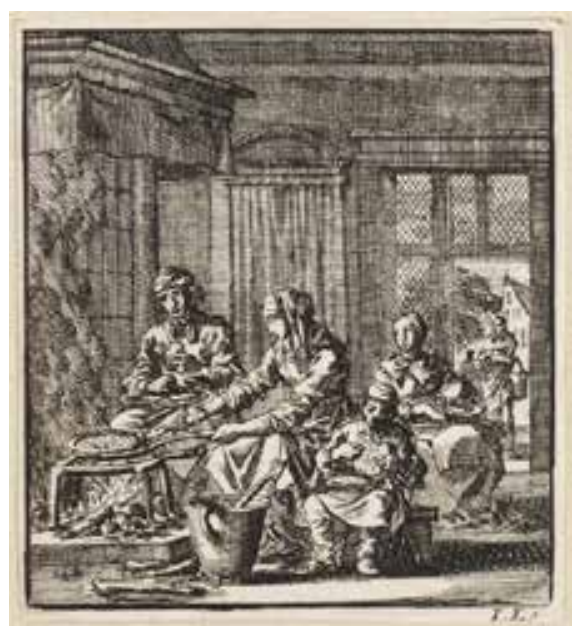

Fig. 10 Jan Luyken, De Pan (The Pan) from Het Leerzam Huisraad, 1711. 
13 It is easy to see why these images appealed to Millet, a specialist in labor scenes. By the late 1840s, Sensier had begun to put pressure on Millet to focus on scenes of rural life. In 1851, while struggling to pursue his ambition to be a history painter in the competitive Paris art market, Millet received the following advice from his mentor: "My dear, if you wish to be understood apart from those paintings of children, bathers and mythology that you do for sale, you must put your mind to composing rustic scenes." 15 The collector then backed his own statement by purchasing twenty drawings of Millet's field workers and assured him that scènes rustiques would guarantee him one major commission a year. ${ }^{16}$

14 As Christopher Parsons and Neil McWilliam have observed, Sensier's ideological agenda in supporting rustic imagery was to reinforce "values located in the past." ${ }^{17}$ For Sensier, the peasant was a more robust, pious creature than the urban dweller. The inherent virtue of traditional labor, implicit in Millet's work, is explicit in Sensier's review of the Salon of 1869. Chief among Millet's admirable qualities, claimed Sensier, are a submission to nature and an iron-clad resistance to change: "The rustic of today, is he not the same as he has been for a thousand years, and as he shall remain, Man bowed beneath the sun's fire or precipitation's chill, earning his bread by the sweat of his brow?"18

15 Encouragement also came from socialist art critic and Dutch art scholar Théophile Thoré, who championed Millet and Gustave Courbet (1819-1877) at the Salon of 1861 as "country doctors... who come with solid recipes and unshakable health." ${ }^{19}$ What were Dr. Millet's cures for France's sickness?--images of the laborer in the fields and the family at home. Thore claimed that Millet's peasant origins, as opposed to direct study, accounted for Millet's resemblance to the Dutch masters. In praise of Waiting, for example, Millet's 1861 depiction of a scene from theBook of Tobit (one of Rembrandt's favorite bible stories), Thoré wrote: "Rembrandt shared this affection for the story of Tobit, from which he painted several episodes in an informal style, which recalls a bit the peasantesque style of M. Millet." ${ }^{20}$ A clever turn of phrase that inverts their relationship, Thorés assertion that Rembrandt "recalls" Millet casts the Frenchman as the master and the Dutchman the follower. While chronologically impossible, it reflects the fact that works by both artists were simultaneously visible to the nineteenth-century public. The Louvre owned Rembrandt's most dramatic canvas inspired by the Book of Tobit, The Angel Raphael Leaving Tobit and His Family. Visitors wandering through the Louvre after the annual Salon might stop to admire the Rembrandt and think of Millet's portrayal of an earlier moment in the story.

16 In 1861 Thoré encouraged Millet and other Realists to take heart, for if Rembrandt had withstood centuries of critical abuse and still managed to make it into Europe's major collections, they, too, would eventually receive the credit they deserved: "For two centuries now, lovers of grand Italian style have misunderstood Rembrandt, which has not, by the way, prevented him from finding his way into Europe's principal museums and galleries. That ought to give the Realists some consolation for present injustices and hope for the future."21

17 From Millet's perspective, Luyken's chief virtue was that his mild artistic personality did not interrupt the flow of Millet's ideas. Bite-sized details from Rembrandt, Pieter de Hooch (1629-1684), Nicolaes Maes (1634-1693), and other genre painters could be borrowed from Luyken's prints without the interference of the original source. Luyken's De Pan, for example, is based on Rem- 
brandt's celebrated etching The Pancake Woman (1635). From Luyken, Millet could appropriate typical Dutch motifs already once removed. Additionally, the prints' no-nonsense instructional purpose was in line with Millet's espousal of traditional working-class roles. Yet Millet's reworkings are not exact replicas. In The Cooper, for instance, Millet revises Luyken's stylized approach to anatomy, bringing the upper arm into alignment with the rest of his body, and further dramatizing the physical exertion by lowering the perspective so the figure rises above us in profile. Unlike Luyken's DePan, from which it is derived, Young Mother Preparing the Evening Meal eliminates extraneous detail and focuses on the figure, which it enlarges. What began as a central motif on a busy printed page is now a stark, monumental image. Nothing in our visual field competes with this formidable mother, a hieroglyph for hearth and home. Smaller adjustments, characteristic of Millet's sensibility as an academically trained figure painter, contribute to the amplification of the pose. The key ingredients, the monumental figure and its reductive environment, are solutions to which Millet would return repeatedly throughout his career.

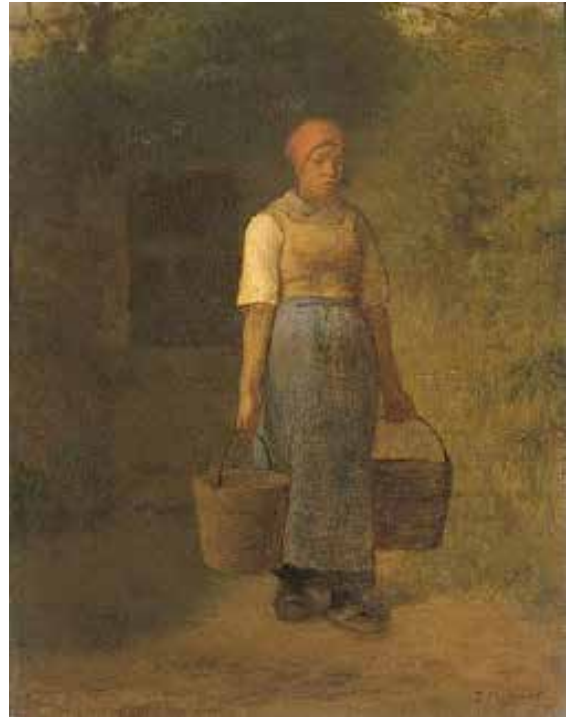

Fig. 11 Jean-François Millet, Woman Returning from the Well (Girl Carrying Water), 1856, oil on canvas, 41 x 33 $\mathrm{cm}$. Rijksmuseum, Amsterdam, (artwork in the public domain)

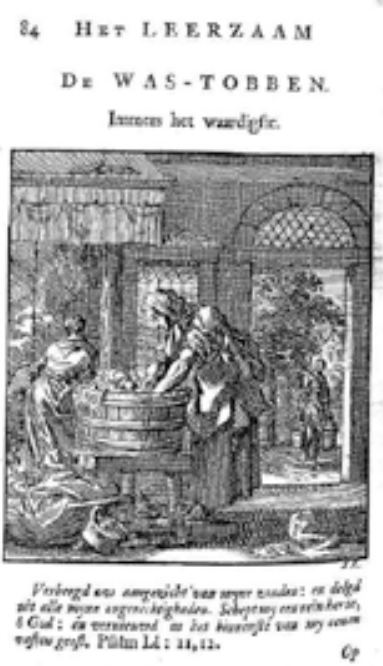

Fig. 12 Jan Luyken, De Was-tobben (The Washtub) from Het Leerzam Huisraad, 1711.

Nonetheless, Luyken's prints were instrumental in reinforcing Millet's persistent message of simplicity and timelessness. Millet's Woman Returning from the Well (fig. 11) magnifies a detail in the background of Luyken's illustration of a washtub (fig. 12). Weighed down by two buckets, Millet's water-carrier places her weight on the same foot as Luyken's figure). Her form is a perfect symbol for Millet's own draughts, dipped from the ancient well, conveying balance and steadiness to the foreground. The figure in Millet's Woman Sweeping Her Home (fig. 13) holds a long-handled broom in precisely the same stance as the seventeenth-century peasant in Luyken's De Bezem (The Broom) (fig. 14), and the drawing borrows additional spatial elements from Luyken, such as the doorway toward which she is sweeping dust and the doorway behind her through which we glimpse another figure at work. Traditional forms of labor, lifted from Luyken's prints, imparted an ageless quality to Millet's scenes. 


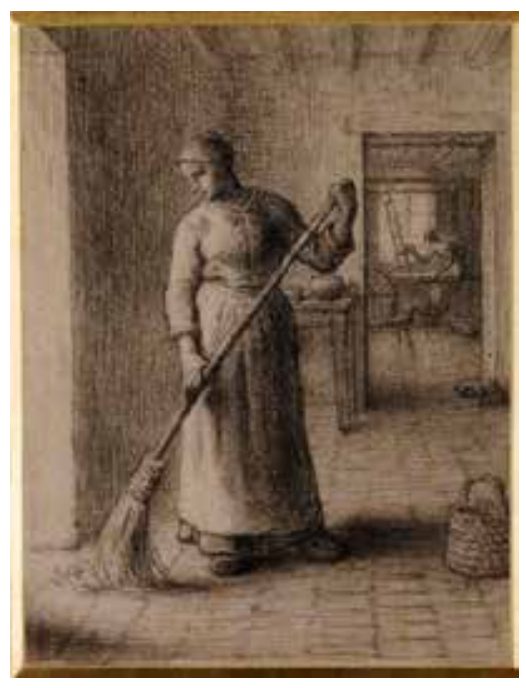

Fig. 13 Jean-François Millet, Woman Sweeping Her Home, 1850s, black chalk on paper, dimensions unknown. Private collection. Christie's, inv. no. CH 401576. Photo: @ Christie's Images / The Bridgeman Art Library.

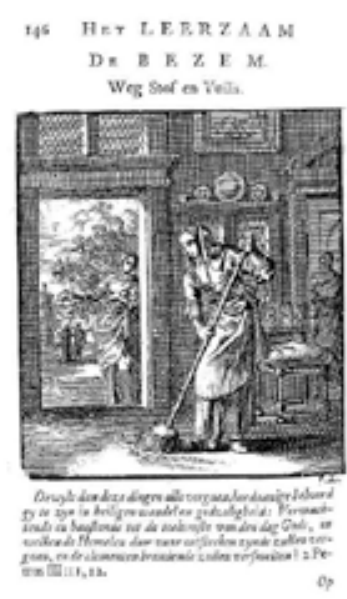

Fig. 14 Jan Luyken, De bezem (Broom) from Het Leerzam Huisraad, 1711.

19 An experience recounted by the American artist Edward Wheelwright illustrates the power of Millet's approach. One Sunday morning in the mid-1850s, Wheelwright and a group of friends stopped by Millet's studio. The artist was not in, but they insisted on a tour, and Millet's brother Pierre obliged, turning canvases that had faced the wall outward one by one. It was the final picture, Woman Mending by Her Sleeping Child (fig. 15), that rendered the audience speechless. As Wheelwright recalled:

At last was brought out from its hiding-place a picture representing the interior of a peasant's cottage. A young mother was seated; knitting or sewing, while with one foot she rocked the cradle in which lay a child asleep ... Through the open window the eye looked out into a garden where a man with his back turned appeared to be at work. The whole scene gave the impression of a hot summer's day; .. . you could almost hear the droning of the bees, and you could positively feel the absolute quiet and repose, the solemn silence, that pervaded the picture. All those at least felt it who saw the picture upon that Sunday morning. A sudden hush fell upon all the noisy and merry party. They sat or stood without breathing. The silence that was in some way painted into the canvas seemed to distill from it into the surrounding air. At last Diaz said in a low voice, husky with emotion, Eh bien, ça, c'est biblique. ${ }^{22}$

20 While any tranquil scene of a mother and infant might invite associations with the Madonna and Child, this one did so with particular force because of its direct, yet tasteful, quotations from another more famous picture: The Carpenter's Household (fig. 16), by Rembrandt. The work was in the prestigious Salon Carrée of the Louvre, and by the 1850s numerous reproductions of it had entered into circulation. When Millet moved to Paris in 1837, it was among the black-and-white illustrations in L'Artiste, and for the Exposition Universelle of 1855, Charles Damour duplicated the composition in an engraving. 


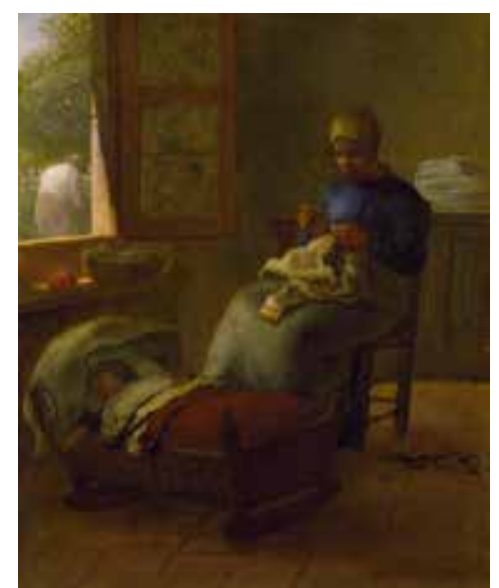

Fig. 15 Jean-François Millet, Woman Mending by Her Sleeping Child, ca. 1855, oil on canvas, $46.4 \times 37.5 \mathrm{~cm}$. Chrysler Museum of Art, Norfolk, Virginia, inv. no. 71.517(artwork in the public domain)

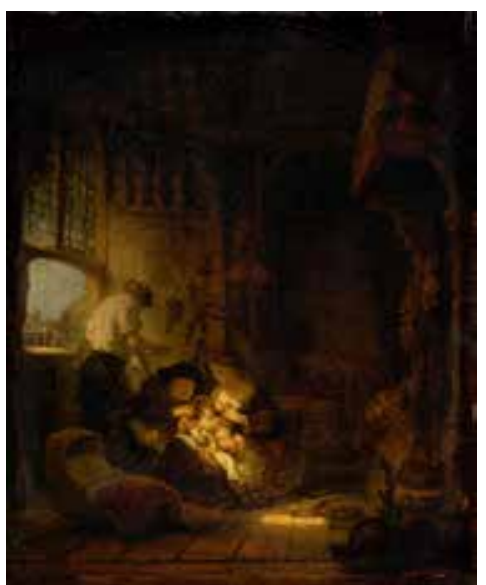

Fig. 16 Rembrandt, The Carpenter's Household, 1640, oil on canvas, $41 \times 34 \mathrm{~cm}$. Musée du Louvre, Paris, inv. no 1742 (artwork in the public domain)

21 When examined side by side, similarities between Millet's Woman Mending by her Sleeping Child and the Dutch masterpiece are immediately visible. Millet's somber interior, the crimson cradle with its diagonal lines leading back into space, the woman seated at its far edge, and the enticing glimpse out the window into the landscape are clearly indebted to the earlier composition. Little wonder Millet's guests found his image biblical. They were predisposed to read it that way. Their unconscious familiarity with the religious scene on which it was based elicited an immediate, collective response from the artists. The most tantalizing link with Rembrandt (singled out for comment in Wheelwright's description) is the male laborer whose crumpled hat, lowered head, and rounded shoulders are taken directly from Saint Joseph in The Carpenter's Household.

22 Woman Mending by Her Sleeping Childis certainly not a copy, nor even an easy homage to Rembrandt. It is a prime example of Millet's shrewdness in employing Dutch figures and themes for his own purposes, and evoking associations without revealing specific sources. ${ }^{23}$ As in his other compositions that borrow from Dutch art, he enlarges the figure of the laborer. In this case he also separates the figures from one another, and in contrast to Rembrandt's cozily crowded space, Millet's interior contains only the mother and child. In accordance with the domestic ideals of the late nineteenth century, he removes the male laborer from the house and eliminates the figure of Saint Ann.

23 Commenting on Millet's compositions in the Salon of 1859, critic Mathilde Stevens wrote, "Labor is the holiest and most fertile form of prayer. That is why Millet's paintings make such an intense and deep impression. These paintings are the most moving and eloquent of prayers, the prayers of simple men, their heads bent towards the earth." ${ }^{24}$ For Millet, as for Luyken (a devout Mennonite), work was the path to salvation and a dimension of his imagery to which viewers responded favorably.

24 As Robert Herbert understood in 1976, the core motifs that serve as the basis for nineteenth-century peasant iconography were drawn as frequently from art as from life. "Without this absorption of earlier arts," he wrote, "peasant genre would not have had such wide currency in the 
nineteenth century, for it would not have had this deeply sensed cultural substructure, it would not have contained these associations--both conscious and unconscious--which surround a form and give it meaning." ${ }^{25}$ Recycled motifs are a common feature of nineteenth-century peasant painting and a crucial stratum of its significance. As Alexandra Murphy more recently acknowledged in her catalogue of Millet's drawings, "in his search for intimate subject matter, Millet must have turned to his favorite old masters, as well as to his own back yard." ${ }^{26}$

25 This goes straight to the heart of Millet's modus operandi, although the artist would surely have denied it. Millet's brilliance lay in his capacity to gauge his audience's appetite for traditional forms and deliver it in the guise of unvarnished truth. Contemporary descriptions of Millet's work supported the mystification of his process. Sensier characterized the artist's drawing, Winter Evening (1867) as possessing "a feeling, a light à la Rembrandt." ${ }^{27}$ In 1875 Paul Mantz, who was a Dutch art specialist actively involved in the revival of Frans Hals (ca. 1581-1666) and no doubt recognized that Millet's debt to the old masters was far from inadvertent, nevertheless praised Millet's "almost unconscious remembrance of methods dear to the old masters." ${ }^{28}$ Millet himself once claimed, to Thoré, that he "avoided with a sort of horror ... anything that bordered on the sentimental." 29

26 At least one nineteenth-century observer was unconvinced by such protests. Camille Pissarro, fifteen years younger and initially an admirer of Millet's work, reacted with exasperation when a friend, Hyacinthe Pozier, burst into tears before The Angelus at the Millet retrospective in 1887. Pissarro dismissed the picture, and Pozier's reaction, as sentimental idiocy:

I went to the Millet exhibition yesterday ... There I ran into Hyacinthe Pozier, he greeted me with the announcement that he had just received a great shock, he was all in tears, we thought someone in his family had died. Not at all; it was The Angelus, Millet's painting which provoked this emotion. This canvas, one of the painter's poorest . . has just this moral effect on the vulgarians who crowd around it: they trample one another before it! This is literally true--and makes one take a sad view of humanity; idiotic sentimentality which recalls the effect Greuze had in the eighteenth century ... a sentimentality that one day will embarrass all true artists. ${ }^{30}$

27 Pissarro's implication is that Millet's work is derivative and lacks on-the-spot immediacy (Jean-Baptiste Greuze [1725-1805], whom Pissarro mentions, also pilfered from Dutch sources). These are refreshing words, coming as they do from a frequent observer of the peasant at work. As someone who preferred to grapple with the frustrations of accurately rendering the natural world, Pissarro recognized Millet's works as manipulative fictions. The utopian anarchist's prediction that Millet's paintings would one day embarrass "true artists" was, however, far from the mark. Less savvy artists, including the young Vincent van Gogh, would soon be inspired to abandon the traditional rigors of the painter's craft in favor of spontaneous recording from life, believing that was precisely what Millet had done.

\section{Acknowledgements}

If my insights in this essay are at all valuable, it's because they rest on the techniques of visual 
analysis in which Egbert trains all his students. From him we learn to look closely, patiently and unpretentiously, and always to support our observations with meticulous research. I thank him for his razor-sharp intellect, his personal gentleness and, most of all, for the lifelong gift of his teaching.

Johanna Ruth Epstein is an Assistant Professor at Hollins University. Her forthcoming book Dutch Courage: How Courbet, Millet and Van Gogh Listened to the Critics and Studied the Masters explores how perceptions of Dutch art in France helped lay the foundation for Modern Art. Her art reviews appear in ARTnews.

\section{List of Illustrations}

Fig. 1 Jean-François Millet, Daphnis and Chloé, ca. 1848-50, black chalk on paper, 11.4 x $20.2 \mathrm{~cm}$. National Gallery of Canada, Ottawa, inv. no. 338 (artwork in the public domain)

Fig. 2 Rembrandt, Jupiter and Antiope: The Larger Plate, 1659, etching, engraving, and drypoint, first state, 13.8 x $20.4 \mathrm{~cm}$. Pierpont Morgan Library, New York, inv. no. RvR 289 (artwork in the public domain)

Fig. 3 Jean-François Millet, Femme à moitié nue, étendue au pied d’une meule (Half-naked woman, lying at the base of a haystack), ca. 1846, black chalk on paper, $18.2 \mathrm{~cm} \mathrm{x} 32.2 \mathrm{~cm}$. Musée du Louvre, Département des arts graphiques, Paris, inv. no. RF 5226, recto (artwork in the public domain) Photo: (c) Musée du Louvre

Fig. 4 Jacques Adrien Lavieille (1818-1862) after Jean-François Millet, printed by Jules Claye, Noon, 1860, wood engraving on paper, 14.8 x $22 \mathrm{~cm}$. The Art Institute of Chicago, inv. no. 1944.75 (artwork in the public domain)

Fig. 5 Jean-François Millet, Christ among the Doctors, mid-1840s, graphite on paper, 19.2 x 30.1 $\mathrm{cm}$. Musée du Louvre, département des Arts graphiques, Paris, inv. no. RF 5883, recto (artwork in the public domain) Photo: (c) Musée du Louvre

Fig. 6 Rembrandt, Christ among the Doctors, 1652, etching and drypoint, 12.6 x $21.4 \mathrm{~cm}$. Fine Arts Museums of San Francisco, inv. no. FASF.1821 (artwork in the public domain)

Fig. 7 Jean-François Millet, The Cooper, ca. 1848-50, oil on canvas, 45.1 x $33.0 \mathrm{~cm}$. Museum of Fine Arts Boston, inv. no. 17.1500 (artwork in the public domain) Photo: (c) MFA Boston

Fig. 8 Jan Luyken, Kuiper (Cooper) from Het Leerzam Huisraad, 1711.

Fig. 9 Jean-François Millet, Young Mother Preparing the Evening Meal, 1848-50, pen and brown ink on paper, $20.8 \times 16.8 \mathrm{~cm}$. National Gallery of Canada, Ottawa, inv. no. 339 (artwork in the public domain)

Fig. 10 Jan Luyken, De Pan (The Pan) from Het Leerzam Huisraad, 1711. 
Fig. 11 Jean-François Millet, Woman Returning from the Well (Girl Carrying Water), 1856, oil on canvas, 41 x $33 \mathrm{~cm}$. Rijksmuseum, Amsterdam (artwork in the public domain)

Fig. 12 Jan Luyken, De Was-tobben (The Washtub) from Het Leerzam Huisraad, 1711.

Fig. 13 Jean-François Millet, Woman Sweeping Her Home, 1850s, black chalk on paper, dimensions unknown. Private collection. Christie’s, inv. no. CH 401576. Photo: (C) Christie’s Images / The Bridgeman Art Library.

Fig. 14 Jan Luyken, De bezem (Broom) from Het Leerzam Huisraad, 1711.

Fig. 15 Jean-François Millet, Woman Mending by Her Sleeping Child, ca. 1855, oil on canvas, 46.4 x $37.5 \mathrm{~cm}$. Chrysler Museum of Art, Norfolk, Virginia, inv. no.71.517(artwork in the public domain)

Fig. 16 Rembrandt, The Carpenter's Household, 1640, oil on canvas, 41x34 cm. Musée du Louvre, Paris, inv. no 1742 (artwork in the public domain)

${ }^{1}$ Jean Duchesne, Notice des estampes exposées à la Bibliothèque Royale (Paris: C. Heideloff, 1837), 64-73. Catalogue nos. 100-17 are by Rembrandt.

${ }^{2}$ Robert Herbert, Jean-François Millet, exh. cat. (London: The Hayward Gallery, 1976),14. Herbert remarks that the drawing, "recalls Jupiter and Antiope by Rembrandt, whose composition forms a prototype for Millet's." For a more recent and comprehensive discussion of nineteenth-century responses to Rembrandt see, Alison McQueen, The Rise of the Cult of Rembrandt: The Power of Rembrandt in Nineteenth-Century France (Amsterdam: Amsterdam University Press, 2003). http://dx.doi.org/10.5117/9789053566244

${ }^{3}$ A drawing with a sleeping couple, early 1850 s, comprised an intermediate step in this process. It has been lost since the Sensier sale (Drouot, Paris, Dec. 10-12, 1877, no. 265; Charles Yriarte, J.F. Millet [Paris: J Rouam, 1885], 52, ill.).

${ }^{4}$ Alfred Sensier, Jean-Francois Millet, trans. Helena de Kay (Boston: Houghton Mifflin, 1896), 52.

${ }^{5}$ For example, when the painter Edward Wheelwright wanted to buy Shepherdess Seated on a Rock (Cincinnati Art Museum, inv. no1940.984) and it was already spoken for, Millet had no qualms about making him another just like it. Winter Evening (Museum of Fine Arts, Boston, inv. no. 17.1520), commissioned by the collector Émile Gavet in 1865, is a pastel version of the composition included in Les Quatres Heures du jour, engravings designed by Millet and published by Jacques-Adrien Lavieille in 1860.

${ }^{6}$ Sensier, Jean-Francois Millet, 41-42.Although none of Millet's copies after engravings have survived, one can safely assume that Dutch engravings were among the works Dumouchel assigned. ${ }^{7}$ Robert Herbert, "City vs. Country: The Rural Image in French Painting from Millet to Gauguin," ArtForum, 8, no. 6 (Feb. 1970): 44-55. A more recent investigation of Millet's sources is Maura Coughlin, "The Artistic Origins of the French Peasant Painter, Jean-François Millet: Between Normandy and Barbizon”(PhD diss., New York University, 2001). See also her discus- 
sion of the origins of Millet's milkmaids in popular imagery: Maura Coughlin, "Millet's Milkmaids," Nineteenth-Century Art Worldwide 2, no. 1 (Winter 2003): www.19thcartworldwide.org/ index.php/winter03/247-millets-milkmaids (accessed June 2, 2011).

${ }^{8}$ Petra ten-Doesschate Chu, French Realism and the Dutch Masters: The Influence of Dutch Seventeenth-Century Painting on the Development of French Painting between 1830 and 1870 (Utrecht: Haentjens Dekker and Gumbert, 1974), 37-39.

Other authors have suggested that the impetus for Millet's focus on the art of the Netherlands in the 1850s was indirect. Alexandra Murphy, for example, believes it came through the work of Chardin. See Alexandra R. Murphy, Jean-François Millet: Drawn into the Light, exh. cat. (Boston: Museum of Fine Arts, 1984), 91.

${ }^{9}$ Alfred Sensier, “Salon de 1866," L’Epoque, May 8, 1866 ( $1^{\text {st }}$ article) (published under the pseudonym Jean Ravenel). Quoted in Christopher Parsons and Neil McWilliam, "Le Paysan de Paris': Alfred Sensier and the Myth of Rural France," Oxford Art Journal 6, no. 2 (1983): 55. For later views, see Coughlin, Artistic Origins of the French Peasant Painter.

http://dx.doi.org/10.1093/oxartj/6.2.38

${ }^{10}$ See Bruce Laughton, The Drawings of Daumier and Millet, (London and New Haven: Yale University Press, 1991), 78

${ }^{11}$ Letter, Barbizon, April 7, 1865: Sensier, Jean-François Millet, 182-83.

12 "Un lot de gravures de Rembrandt, Jan Luyken, Van Ostade, etc. 45 pièces": Vente Veuve Millet, sale cat., Hôtel Drouot, Paris, April 24-25, 1894.

${ }^{13}$ Het Menselyk Bedryf (The Book of Trades) was published in 1694 and Het Leerzaam Huisraad (The Tutelary Household) in 1711.

${ }^{14}$ Two sources have been proposed previously. Herbert, "City vs. Country," 94, notes that this is a traditional pose for coopers and claims that Clément-Auguste Andrieux's illustration for Pierre Dupont's Le Tonnelier (1853) is in "the same pose," while Murphy, Jean-François Millett, 46, points to Edmé Bouchardon's illustration from the Cris de Paris (Paris: Fessard, 1737-46), as a possible source. Neither the cooper of Andrieux (1829-after 1880) nor that of Bouchardon (1698-1762) resemble, in my opinion, Millet's active figure as closely as does Luyken's.

${ }^{15}$ Quoted in Laughton, Drawings of Daumier and Millet, 78.

${ }^{16}$ Sensier bought these with the intention of having them made into a series of prints. The series was never completed.

${ }^{17}$ Parsons and McWilliam, “Le Paysan de Paris," 39. http://dx.doi.org/10.1093/oxartj/6.2.38 ${ }^{18}$ Alfred Sensier, "Le paysage et les Paysans"(part of the review of the Salon of 1869), Revue Internationale de l'Art et de la Curiosité 1, no. 5 (May 1869), 399. Quoted in Parsons and McWilliam, “Le Paysan de Paris," 39. http://dx.doi.org/10.1093/oxartj/6.2.38

${ }^{19}$ Linda Nochlin, Realism and Tradition in Art, 1848-1900: Sources and Documents (Englewood Cliffs, N.J.: Prentice-Hall, 1966), 55. Théophile Thoré (pseud. W. Bürger), “Salon de 1861," in Salons de W. Bürger, 1861-1868,(Paris: Librairie Renouard, 1870), 1:93.

${ }^{20}$ Thoré, Salons de W. Bürger, 1:96. Perhaps in anticipation of this connection made by Thoré and presumably others, Millet's picture mirrors Rembrandt's composition in reverse, presenting the left-hand figure from the back, and the right-hand figure in a rustic doorway.

${ }^{21}$ Thoré, "Salon de 1861, " in Salons de W. Bürger, 1:96.Both Thoré and Millet were no doubt familiar with Prosper Louis Roux's imaginative etching of Rembrandt's studio, which appeared at the Salon of 1857. In it theAngel Raphael Leaving the Family of Tobit, owned by the Louvre, occupies an easel in the background, while three seventeenth-century connoisseurs lean in to examine 
it. Roux depicts Rembrandt enjoying the critical attention that Thore envisioned for the Realists of his own time.

${ }^{22}$ Edward Wheelwright, "Personal Recollections of Jean-François Millet," Atlantic Monthly 38 (Sept. 1876): 272-73.

${ }^{23}$ In order to avoid appearing derivative, Millet borrowed the infant lying on its back beneath a coverlet, from which a tiny arm escapes, from Luyken's illustration of a cradle. Luyken himself had borrowed the cradle from Rembrandt's Virgin and Child with Angels (The Hermitage, St. Petersburg).

${ }^{24}$ Mathilde Stevens, “Impressions d'une femme au Salon de 1859," Le Monte Cristo 7, no. 2 (June 1859): 99. Translated in Parsons and McWilliam, “Le Paysan de Paris,” 56.

http://dx.doi.org/10.1093/oxartj/6.2.38

${ }^{25}$ Herbert, "City vs. Country," 50.

${ }^{26}$ Murphy, Jean-François Millet, 115.

${ }^{27}$ Alfred Sensier, La vie et l'oeuvre de J.-F. Millet (Paris: A. Quantin), 1881, 301, 302n1.

${ }^{28}$ Paul Mantz, “J. -F. Millet,"Le Temps, March 2, 1875, 3.

${ }^{29}$ Sensier, Jean-François Millet, 141.

${ }^{30}$ Camille Pissarro: Letters to His Son Lucien, ed. John Rewald (New York: Pantheon, 1943), 11011.

\section{Bibliography}

Chu, Petra ten-Doesschate. French Realism and the Dutch Masters: The Influence of Dutch Seventeenth-Century Painting on the Development of French Painting between 1830 and 1870. Utrecht: Haentjens Dekker and Gumbert, 1974.

Coughlin, Maura. “Millet's Milkmaids.” Nineteenth-Century Art Worldwide2, no. 1 (Winter 2003). www.19thcartworldwide.org/index.php/winter03/247-millets-milkmaids. Accessed June 2, 2011.

. "The Artistic Origins of the French Peasant Painter, Jean-François Millet: Between

Normandy and Barbizon."PhD diss., New York University, 2001.

Duchesne, Jean. Notice des estampes exposées a la Bibliothèque Royale. Paris: C. Heideloff, 1837.

Herbert, Robert. "City vs. Country: The Rural Image in French Painting from Millet to

Gauguin.” ArtForum 8, no. 6 (Feb. 1970): 44-55.

. Jean-François Millet. Exh. cat. London: The Hayward Gallery, 1976.

Laughton, Bruce. The Drawings of Daumier and Millet. London and New Haven: Yale University Press, 1991.

Luyken, Jan. Het Leerzaam Huisraad. Amsterdam, 1711. . Het Menselyk Bedryf. Amsterdam, 1694. 
Mantz, Paul. “J.-F. Millet.” Le Temps, March 2, 1875.

McQueen, Alison. The Rise of the Cult of Rembrandt: The Power of Rembrandt in Nineteenth-Century France. Amsterdam: Amsterdam University Press, 2003. http://dx.doi. org/10.5117/9789053566244

Murphy, Alexandra R. Jean-François Millet: Drawn into the Light. Exh. cat. Boston: Museum of Fine Arts, 1984.

Nochlin, Linda. Realism and Tradition in Art, 1848-1900: Sources and Documents. Englewood Cliffs, N.J.: Prentice-Hall, 1966.

Parsons, Christopher, and Neil McWilliam. “Le Paysan de Paris': Alfred Sensier and the Myth of Rural France." Oxford Art Journal 6, no. 2 (1983): 38-58. http://dx.doi.org/10.1093/oxartj/6.2.38

Pissarro, Camille. Camille Pissarro: Letters to His Son Lucien. Edited by John Rewald. New York: Pantheon, 1943.

Sensier, Alfred (pseud. Jean Ravenel). “Salon de 1866.” L’Epoque, May 8, 1866.

Sensier, Alfred. "Le paysage et les Paysans." Revue Internationale de l'Art et de la Curiosité 1, no. 5 (May 1869): 385-406. . Jean-Francois Millet. Translated by Helena de Kay. Boston: Houghton Mifflin, 1896.

Sensier, Alfred, and Paul Mantz. La vie et l'oeuvre de J.-F. Millet. Paris: A. Quantin, 1881.

Stevens, Mathilde. "Impressions d'une femme au Salon de 1859." Le Monte Cristo 7, no. 2 (June 1859): 99.

Théophile Thoré (pseud. W. Bürger). Salons de W. Bürger, 1861-1868. 2 vols. Paris: Librairie Renouard, 1870.

Vente Veuve Millet. Sale cat.: Hôtel Drouot, Paris, April 24-25, 1894.

Wheelwright, Edward. "Personal Recollections of Jean-François Millet." Atlantic Monthly 38 (Sept. 1876): 272-73.

Recommended Citation:

Johanna Ruth Epstein "Incapable of That Sort of Thing: Millet's Dutch Sources," JHNA 5:2 (Summer 2013), DOI: 10.5092/

jhna.2013.5.2.17 